\title{
SOSIALISASI DAMPAK STUNTING PADA BALITA DI DESA PASIE JAMBU KECEMATAN KAWAI XVI KABUPATEN ACEH BARAT
}

\author{
Susy Sriwahyuni', Khairunnas ${ }^{2}$ \\ 1Jurusan Kesehatan Masyarakat, Universitas Teuku Umar \\ Email: susysriwahyuni@utu.ac.id \\ 2Jurusan Gizi, Universitas Teuku Umar \\ Email: khairunnas@utu.ac.id
}

Submitted: 03-06-2020

Revised: 01-09-2020

Accepted: $25-12-2020$

\begin{abstract}
Malnutrition is the worst form of the process of chronic malnutrition. Healthy toddlers or malnourished children can simply be known by comparing the weight according to age with the reference (standard) that has been set. If the weight according to age matches the standard, the child is called good nutrition. If it is slightly below standard, it is called malnutrition If it is far below the standard, it is called malnutrition. According to the Aceh Ministry of Health, in 2017 there were around 27.5\% (5 million undernourished children), 3.5 million children (19.2\%) underweight and 1.5 million malnourished children (8.3\% ). WHO in 2008 grouped regions based on the prevalence of malnutrition into four groups, namely low (<10\%), moderate (10-19\%), high (20-29\%) and very high $(>30 \%)$. Servitude of this using descriptive methods that describe the results of devotion made and socializing the danger of malnutrition to toddlers to the community in Pasie Jambu village. The implementation of the socialization program was attended by the community and community leaders. The number of people who participated in the socialization program were 30 people.
\end{abstract}

Keywords: Knowledge, Attitudes, Actions, Malnutrition

\begin{abstract}
Abstrak
Gizi buruk adalah bentuk terparah dari proses terjadinya kekurangan gizi menahun. Anak balita sehat atau kurang gizi secara sederhana dapat diketahui dengan membandingkan antara berat badan menurut umur dengan rujukan (standar) yang telah ditetapkan. Apabila berat badan menurut umur sesuai dengan standar, anak disebut gizi baik, apabila dibawah standar disebut dengan gizi kurang, dan apabila jauh dibawah standar disebut gizi buruk. Menurut Departemen Kesehatan Aceh, pada tahun 2017 terdapat sekitar 27,5\% (5 juta balita kurang gizi), 3,5 juta anak $(19,2 \%)$ dalam tingkat gizi kurang dan 1,5 juta anak gizi buruk $(8,3 \%)$. Sedangkan untuk Pada tahun 2018 Aceh Barat mengalami kasus 20 kasus gizi . Pengabdian ini menggunakan Metode deskriptif yaitu menggambarkan hasil pengabdian yang dibuat dan mensosialisasikan dampak bahaya gizi buruk terhadap balita kepada masyarakat di desa Pasie Jambu. Pelaksanaan program sosialisasi ini diikuti oleh masyarakat serta tokoh masyarakat. Masyarakat yang mengikuti dalam program sosialisasi yaitu berjumlah 30 (tiga puluh) orang..
\end{abstract}

Kata Kunci: Balita, Pengetahuan, Status Gizi

\section{PENDAHULUAN}

Masalah gizi merupakan

masalah yang ada di tiap-tiap negara, baik negara miskin, negara berkembang dan negara maju. Negara miskin cenderung dengan 
masalah gizi kurang, hubungan dengan penyakit infeksi dan negara maju cenderung dengan masalah gizi lebih (Lestrina, 2009).

Saat ini di dalam era globalisasi dimana terjadi perubahan gaya hidup dan pola makan, Indonesia menghadapi permasalahan gizi ganda. Di satu pihak masalah gizi kurang yang pada umumnya disebabkan oleh kemiskinan, kurangnya persediaan pangan, kurang baiknya kualitas lingkungan, kurangnya pengetahuan masyarakat tentang gizi. Selain itu masalah gizi lebih yang disebabkan oleh kemajuan ekonomi pada lapisan masyarakat tertentu disertai dengan kurangnya pengetahuan tentang gizi. (Prakarya et al., 2008)

Penanganan gizi buruk sangat terkait dengan strategi sebuah bangsa dalam menciptakan sumber daya manusia yang sehat, cerdas, dan produktif. Upaya peningkatan sumber daya manusia yang berkualitas dimulai dengan cara penanganan pertumbuhan anak sebagai bagian dari keluarga dengan asupan gizi dan perawatan yang baik (Arnelia, 2011). Dengan lingkungan keluarga yang sehat, maka hadirnya infeksi menular ataupun penyakit masyarakat lainnya dapat dihindari. Di tingkat masyarakat faktor-faktor seperti lingkungan yang higienis, ketahanan pangan keluarga, pola asuh terhadap anak dan pelayanan kesehatan primer sangat menentukan dalam membentuk anak yang tahan gizi buruk. (Maulina, 2012)

Secara makro, dibutuhkan ketegasan kebijakan, strategi, regulasi, dan koordinasi lintas sektor dari pemerintah dan semua stakeholders untuk

menjamin terlaksananya poin-poin penting seperti pemberdayaan masyarakat, pemberantasan kemiskinan, ketahanan pangan, dan pendidikan yang secara tidak langsung akan mengubah budaya buruk dan paradigma di tataran bawah dalam hal perawatan gizi terhadap keluarga termasuk anak.

Keberhasilan pembangunan nasional yang diupayakan oleh pemerintah dan masyarakat sangat ditentukan oleh ketersediaan sumber daya manusia. Indikator yang digunakan untuk mengukur tinggi rendahnya kualitas sumber daya manusia antara lain Indeks Pembangunan Manusia (IPM) dan Indeks Kemiskinan Manusia (IKM). Pada umumnya IPM dan IKM mempunyai komponen yang sama, yaitu angka harapan hidup (tingkat kesehatan), penguasaan ilmu pengetahuan (tingkat pendidikan) dan standar kehidupan yang layak (tingkat ekonomi). Pada IPM, standar hidup layak dihitung dari 
pendapatan per kapita, sementara IKM diukur dengan persentase penduduk tanpa akses terhadap air bersih, fasilitas kesehatan, dan balita kurang gizi.(Masro et al., 2014)

Tiga faktor utama penentu IPM adalah tingkat pendidikan, kesehatan, dan ekonomi. Ketiga faktor tersebut erat kaitannya dengan status gizi masyarakat. Pada tahun 2003 IPM Indonesia pada peringkat 112 dari 175 negara, sementara IKM pada peringkat 33 dari 94 negara.

Badan Pusat Statistik (2018) penduduk miskin adalah penduduk yang memiliki rata-rata pengeluaran per kapita perbulan dibawah garis kemiskinan. Dalam Berits Resmi Statistik No 06/01/Th. XVI, 2 Januari 2013 profil kemiskinan di indonesia September 2012 jumlah penduduk miskin mencapai 28,59 juta orang $(11,66$ persen). Jika di bandingkan dengan jumlah penduduk miskin pada maret 2012, maka selama 6 bulan tersebut terjadi pertambahan penduduk miskin sebesar 0,54 juta orang.(BPS, 2018)

Masalah ketahanan pangan nasional merupakan masalah yang harus ditangani secara bersama. Tidak hanya mengandalkan pemerintah, namun harus didukung dengan dengan keikutsertaan secara aktif masyarakat dimulai lini terkecil pembentuk masyarakat yaitu keluarga. Oleh karenanya pengetahuan ketahanan pangan keluarga secara signifikan akan mampu mengatasi permasalahan ketahanan pangan secara umum (Tando, 2018). Rumah pangan merupakan salah satu konsep pemanfaatan lahan pekarangan baik didesa maupun di perkotaan untuk mendukung ketahanan pangan nasional dengan memberdayakan potensi pangan lokal. Pekarangan bukan hanya untuk menciptakan keindahan dan kesejukan saja, tetapi lebih dari pada itu adalah guna meningkatkan perekonomian keluarga masing-masing. Jenis-jenis tanaman yang bisa ditanam dipekarangan rumah masingmasing adalah jenis sayur-sayuran, buah-buahan, tanaman hias, dan lain sebagainya. (Ayuning Tyas, 2019)

Salah satu prioritas pembangunan nasional di bidang kesehatan adalah upaya perbaikan gizi yang berbasis pada sumber daya, kelembagaan, dan budaya lokal. Kurang gizi akan berdampak pada penurunan kualitas SDM yang lebih lanjut dapat berakibat pada kegagalan pertumbuhan fisik, perkembangan mental dan kecerdasan, menurunkan produktivitas, meningkatkan kesakitan serta kematian. Visi pembangunan gizi adalah "Mewujudkan keluarga mandiri 
sadar gizi untuk mencapai status gizi masyarakat/keluarga yang optimal".

Secara umum di Indonesia terdapat dua masalah gizi utama, yaitu kurang gizi mikro dan kurang gizi makro. Kurang gizi makro pada umumnya disebabkan oleh kekurangan asupan energi dan protein dibanding kebutuhannya yang menyebabkan gangguan kesehatan, sedangkan kurang gizi mikro disebabkan kekurangan zat gizi mikro (Kurniawati, 2012). Gizi buruk adalah bentuk terparah dari proses terjdinya kekurangan gizi menahun. Anak balita sehat atau kurang gizi secara sederhana dapat diketahui dengan membandingkan antara berat badan menurut umurnya dengan rujukan (standar) yang telah ditetapkan. Apabila berat badan menurut umur sesuai dengan standar, anak disebut gizi baik. Kalu sedikit dibawah standar disebut gizi kurang. Apabila jauh dibawah standar disebut gizi buruk. Menurut Departemen Kesehatan, pada tahun 2010 terdapat sekitar 27,5\% (5 juta balita kurang gizi), 3,5 juta anak $(19,2 \%)$ dalam tingkat gizi kurang dan 1,5 juta anak gizi buruk (8,3\%). WHO tahun 2008 mengelompokan wilayah berdasarkan prevalensi gizi kurang ke dalam empat kelompok, yaitu rendah $(<10 \%)$, sedang (10$19 \%)$, tinggi (20-29\%) dan sangat tinggi $(>30 \%)$.
Atas dasar hal tersebut diatas, maka tim pengabdian masyarakat merasa perlu untuk melakukan kegiatan sosialisasi ini, sehingga stunting dapat dicegah dan dampak buruk dari stunting bisa di cegah sedini mungkin.

\section{METODE PELAKSANAAN}

Sifat dari pengabdian ini yaitu deskriptif yaitu menggambarkan hasil pengabdian yang dibuat dan mensosialisasikan dampak bahaya gizi buruk terhadap balita kepada masyarakat di Desa Pasie Jambu, Kecamatan Kaway XVI Kabupaten Aceh Barat. Pelaksanaan Program Sosialisasi ini diikuti oleh masyarakat serta tokoh masyarakat. Dalam pengabdian ini telah dijadikan informan yaitu tokoh masyarakat serta masyarakat di desa tersebut.

\section{a. Lokasi pengabdian}

Lokasi penelitian ini mengenai pelaksanaan sosialisasi penanggulangan gizi buruk di desa pasie jambu Kecematan Kawai XVI Kabupaten Aceh Barat program sosialisasi ini dilakukan di balai desa serba guna, dimana sosialisasi ini beralamat di desa Pasie. Lokasi pengabdian ini merupakan tempat dimana semua masyarakat melakukan kegiatan dan termpat pengabdian ini merupakan salah satu temnpat zona banyaknya balita yang perlu diberikan gizi seimbang. 
Lokasi pengabdian tersebut merupakan tempat pengabdian yang diharapkan mampu memberikan informasi mengenai sosialisasi gizi buruk kepada masyarakat desa tersebut.

\section{b. Konsep Kegiatan}

Potensi untuk dilakukan sosialisasi mengenei gizi buruk kepada msyarakat Desa Pasie Jambu ialah sangat diperlukan. Karena banyaknya balita di desa tersebut, dan dirasa harus memberikan pengetahuan kepada masyarakat terutama kepada para Ibu-Ibu Desa Pasie Jambu tersebut. Dimana pemberian informasi tersebut memberikan dampak langsung yang bagus terhadap pengetahuan Ibu yang secara tidak langsung akan berdampak baik kepada balita- balita di desa tersebut (Hardinsyah \& Supariasah, 2017). Selin itu, diharapkan juga masyarakat mengerti akan bahayanya dampak gizi buruk kepada balita. Oleh karena itu tujuan dari pengabdian ini ialah memberikan pengetahuan serta informasi mengenai bahayanya dampak gizi buruk terhadap balita.

\section{c. Strategi pelaksanaan}

Sosialisasi ini dilakukan oleh Tim Pengusul Pengabdian serta melibatkan 1 (satu) kelompok mahasiswa yang beranggotakan 5 orang untuk memberika MP (Makanan Pendamping) dan menyiapkan peralatan-peralatan sebelum memberikan informasi kepada masyarakat seperti infokus, layar monitor, dll. Sosialisasi ini bermanfaat untuk masyarakat di Desa Pasie Jambu agar memberikan anak-anak mereka gizi seimbang dan terhindar dari gizi buruk.

Kegiatan ini akan dilaksakan dalam 2 (dua) tahap yaitu :

a) Tahap perkenalan

Pada tahap ini yaitu mengenali koseler penyuluh dan apa-apa yang yang akan di sosialisasi serta melakukan pendekatan kepada tokoh masyarakat.

b) Tahap Sosialisasi

Pada tahap ini penyuluh melakukan sosialisasi mengenai dampak bahaya gizi buruk terhadap balita kepada masyarakatdi Desa Pasie Jambu.

\section{HASIL DAN PEMBAHASAN}

Kegiatan Sosialisasi dengan tema "Dampak Bahaya Gizi Buruk Terhadap Balita Kepada Masyarakat di Desa Pasie Jambu, Kecamatan Kaway XVI Kabupaten Aceh Barat" ini dihadiri oleh Ibu-ibu yang memiliki Balita serta para Tokoh Masyarakat yang ada di Desa setempat, pada kegiatan ini yang terpenting kita memperoleh hasil yaitu dengan antusias nya Ibu-ibu dalam mendengarkan sosialisasi yang diberikan oleh pemateri. 
Kegiatan sosialisasi ini diberikan untuk Ibu-ibu yang memiliki Balita serta para Tokoh Masyarakat, dengan focus utama untuk meningkatkan pengetahuan Ibu dan para Tokoh Masyarakat terhadap dampak Stunting bagi anak.

Kegiatan ini dilaksanakan oleh 2 (dua) dosen dari Fakultas Kesehatan Masyarakat Universitas Teuku Umar yaitu Ibu Susy Sriwahyuni, SKM, M.Si dan Bapak Khairunnas, DCN, M.Kes dan melibatkan 5 orang Mahasiswa Fakultas Kesehatan Masyarakat

Sosialisasi ini dilakukan dalam rangka memperingati Hari Kesehatan Nasional (HKN) dengan dilakukan Sosialisasi Damapak Buruk Stunting Bagi Anak, dimana pada Intervensi yang dilakukan yaitu memberikan sosialisasi serta membagikan MP (Makanan Pendamping) bagi Balita yang ada di Desa Pasi Jambu Kecamatan Kaway XVI Kabupaten Aceh Barat. Salah satu tujuan kami melakukan kegiatan tersebut adalah sebagai upaya untuk meningkatkan pengetahuan Ibu terhadap dampak bahaya bagi balita, karena begitu banyaknya dampak negatif yang diakibatkan dari stunting terutama tumbuh kembang otak anak menjadi terganggu, yang berakibat pada tingkat kecerdasan anak yang rendah. Selain itu upaya pemberian MP (Makanan Pendamping) ini bertujuan untuk meningkatkan gizi anak, karena pada masa pertumbuhan ini diperlukan banyak sekali nutrisi dan gizi untuk tumbuh kembang anak, dimana kami memberikan contoh makanan pendamping yang sangat bagus untuk pertumbuhan anak, seperti Susu Kedelai, serta olahan makanan yang tinggi akan protein terutama untuk pertumbuhan anak.

Adapun hambatan yang dirasakan selama berjalannya kegiatan ini adalah kurangnya waktu pelaksanaan dikarenakan sebagian Ibu-ibu memiliki kesibukan ketika pagi. Walaupun demikian faktor-faktor pendukung dalam sosialisasi ini adalah besarnya keterkaitan serta minat Ibu-ibu di Desa Pasi Jambu untuk mengikuti kegiatan ini, karena tema yang diangkat pada kegiatan ini merupakan suatu tema yang sedang hangat diperbincangkan dimasyarakat, karena seperti yang kita ketahui pemerintah pusat dan daerah sudah memfokuskan dan menggalakkan program pencegahan stunting, karena tingginya angka kasus stunting di Indonesia, khususnya Aceh yang menempati urutan 3 besar kasus stunting tertinggi di Indonesia.

Berikut ini disajikan fotofoto/ dokumentasi pada saat dilaksanakan Sosialisasi tetkait stunting serta dilakukan 
pengukuran tinggi badan untuk mengetahui status gizi balita terutama Z-Score BB/U (berat badan bayi berdasarkan umur) sehingga diketahui status gizi balita, sebagai berikut :

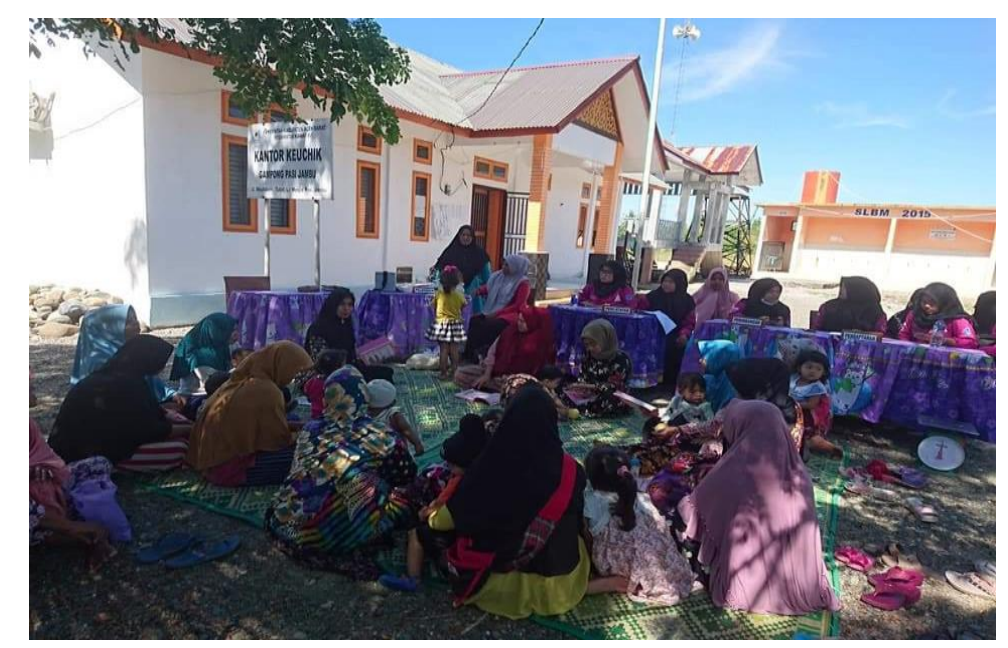

Gambar 1. Pembukaan Kegiatan Sosialisasi dan pemberian Materi terkait Dampak Bahaya Stunting

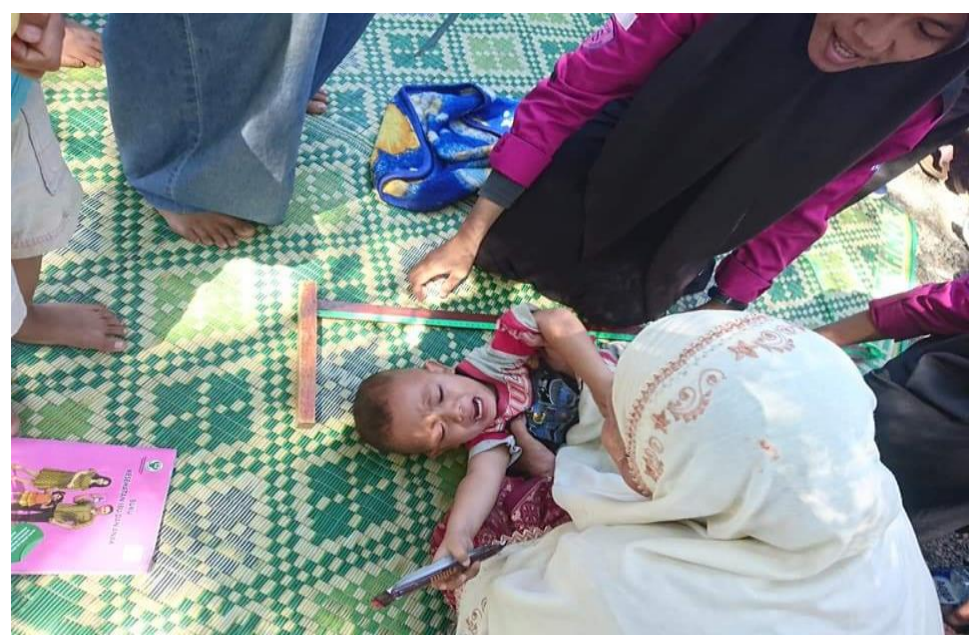

Gambar 2. Pengukuran Tinggi Badan Anak secara terlentang untuk mengetahui Panjang Badan untuk anak dibawah 2 tahun 


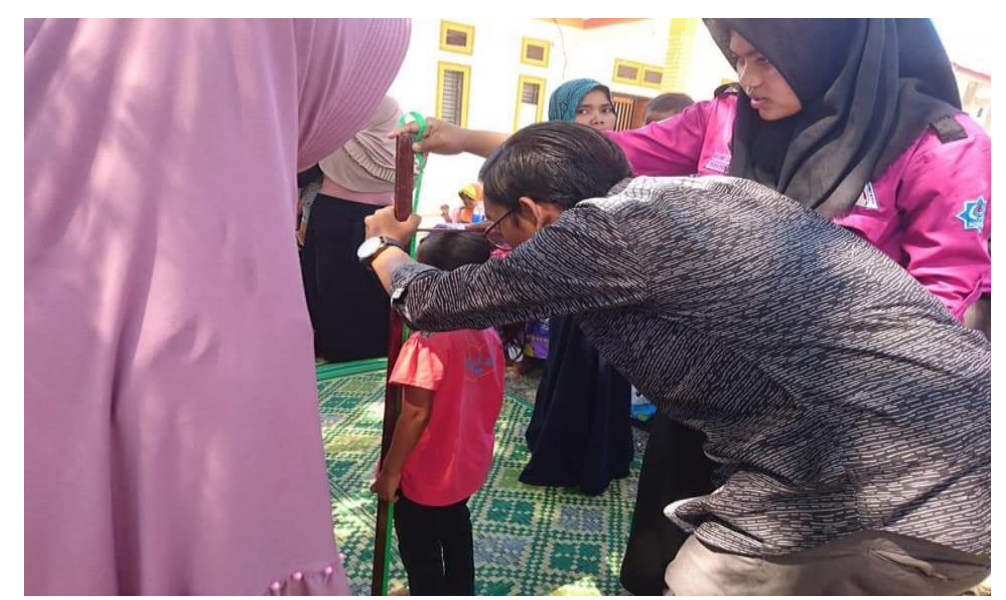

Gambar 3. Pengukuran Tinggi Badan Anak secara berdiri untuk mengetahui Tinggi Badan untuk anak diatas 2 tahun-5 tahun

Dari hasil pelaksanaan
sosialisasi tersebut didapatkan
beberapa poin penting, dimana
Masyarakat khususnya Ibu-ibu
yang memiliki balita belum
mengetahui apa itu stunting,
dampak buruk/ negatif dan
bagaimana cara mengetahui status
gizi anaknya, apakah anaknya
tersebut masuk kedalam kategori
stunting atau tidak, sehingga
dengan diberikannya sosialisasi ini
Ibu-ibu menjadi tahu terkait
stunting dan yang paling utama
Ibu-ibu mengetahui status gizi
anaknya sendiri dan tahu
bagaimana harus bertindak
sehingga tumbuh kembang anak,
normal dan sehat.

\section{PENUTUP}

Dari hasil pengabdian kepada masyarakat yang sudah dilakukan di Desa Pasi Jambu Kecamatan Kaway XVI Kabupaten Aceh Barat ini dapat diambil suatu kesimpulan bahwa peningkatan pengetahuan Ibu terkait Stunting mulai dari pengertian, cara mengukur status gizi anak, status gizi anak, sampai kepada dampak buruk dari stunting sangat penting dilakukan dan harus dilakukan secara terus menerus.

Peningkatan pengetahuan yang terkait stunting sangat berpengaruh terhadap sikap dan tindakan yang akan Ibu lakukan kepada anaknya, sehingga dengan adanya kegiatan pengabdian masyarakat yang dalam hal ini Sosialisasi Dampak Bahaya Stunting pada Balita dapat memberikan efek positif terhadap peningkatan pengetahuan Ibu tentang Stunting.

Maka dari itu melaksanakan sosialisasi serupa pada masyarakat di Desa-Desa lainnya sangatlah diperlukan secara berkala dan terus menerus. 


\section{DAFTAR PUSTAKA}

Arnelia. (2011). Kajian penanganan anak gizi buruk dan prospeknya. The Journal of Nutrition and Food Research, 34(1), 1-11. https://doi.org/10.22435/pgm. v34i1.3106.

Ayuning Tyas, D. N. (2019). Implementasi Kebijakan

Program Kawasan Rumah Pangan Lestari (KRPL) Dalam Meningkatkan Kesejahteraan Masyarakat. Jurnal Inovasi Ilmu Sosial Dan Politik, 1(1), 71-87. https://doi.org/10.33474/jisop .v1i1.2679

BPS. (2018). Profil Kemiskinan di Indonesia Maret 2018. In Badan Pusat Statistik. https://www.academia.edu/d ownload/39606589/data_kemis kinan_indonesia_2015.pdf

Hardinsyah, \& Supariasah, I. D. (2017). Ilmu Gizi Teori dan Aplikasi. Jakarta: Penerbit Buku Kedokteran EGC.

Kurniawati, E. (2012). Hubungan Tingkat Pengetahuan Ibu Tentang Gizi Dengan Status Gizi Balita Di Kelurahan Baledono, Kecamatan Purworejo, Kabupaten Purworejo. Jurnal Komunikasi Kesehatan, 3(2), 22-31. http://ejournal.akbid-

purworejo.ac.id/index.php/jkk 5/article/view/49

Lestrina. (2009). Penanggulangan Gizi Buruk Diwilayah Kerja puskesmas Lubukn Pakam Sumatra Utara
[Universitas Sumatra Utara]. http://repository.usu.ac.id/ha ndle/123456789/6992

Masro, A., Edison, \& Gracediani, L. (2014). Implementasi Penanggulangan Gizi Buruk Di Wilayang Kerja Puskesmas Sungai Limau Kabupaten Padang Pariaman. Jurnal Kesehatan Masyarakat Andalas, $8(1)$, 21-26. https:/ /doi.org/https:/ / doi.or g/10.24893/jkma.v8i1.119

Maulina, N. (2012). Interaksi Pemerintah dan Masyarakat Dalam Implementasi Program Penanggulangan Gizi Buruk di Kota Surabaya: Kajian Biopolitik. Jurnal Politik Muda, 2(1), 145-157.

Prakarya, R. E., Kandarina, I., \& Akhmadi. (2008). Upaya Penanggulangan Gizi Buruk Pada Balita Melalui Penjaringan Dan Pelacakan Kasus. Berita Kedokteran Masyarakat, 24(2), 69-75.

Tando, E. (2018). Optimalisasi Pemanfaatan Pekarangan Melalui Pengembangan Model Kawasan Rumah Pangan Lestari (m-KRPL) dalam Mendukung Penerapan Teknologi Budidaya Sayuran Organik di Sulawesi Tenggara. AGRODADIX: Jurnal Ilmu Pertanian, 2(1), 14-22. http://ejurnal.unisda.ac.id/index.php/ agro/article/view/1281 